Arab World English Journal (AWEJ) Volume 10. Number 4 December 2019

DOI: https://dx.doi.org/10.24093/awej/vol10no4.24

Pp.330 343

\title{
Education 4.0 Technologies, Industry 4.0 Skills and the Teaching of English in Malaysian Tertiary Education
}

\section{Airil Haimi Mohd Adnan}

Department of English \& Linguistics, APB

Universiti Teknologi MARA Perak Branch, Seri Iskandar, Malaysia

Rafidah Abd Karim

Department of English \& Linguistics, APB

Universiti Teknologi MARA Perak Branch, Tapah, Malaysia

Mohd Haniff Mohd Tahir

Department of English \& Linguistics, APB

Universiti Teknologi MARA Perak Branch, Seri Iskandar, Malaysia

Nurul Nadiah Mustafa Kamal

Institute of Postgraduate Studies, APB

Universiti Teknologi MARA Selangor Branch, Shah Alam, Malaysia

Ahmad Muhyiddin Yusof

Department of English \& Linguistics, APB

Universiti Teknologi MARA Perak Branch, Seri Iskandar, Malaysia

\section{Abstract}

Unprecedented changes are happening in the way the world works; traditional jobs are being replaced by new ones that need critical skills for workers of the future. Enter the era of 'Industry 4.0 '. In this era, knowledge and skills are paramount for one to stay relevant and remain competitive in the job market. Terms like 'reskilling' and 'upskilling' reflect the kind of changes that are happening. Thus, it is only natural that the realm of education follows suit, with the construct of 'Education 4.0'. This research article takes a broadly neutral view of Industry 4.0 and Education 4.0, although both constructs are criticized by certain quarters. In truth, the increasing automation of manual labor and remarkable growth in and expansion of technological developments, all point to an uncertain future for the next generation of future workers. Strategies must be drafted, and initiatives be taken, to ensure young people are not disadvantaged in the near future. This article examines the struggles of a small group of English educators at Malaysian public universities, who are frantically trying to apply Education 4.0 learning technologies to teach this international language to Malaysian students, based on three core research questions. Handicapped with little to no budget, limited technical expertise and no institutional assistance, and facing resistance from traditional educators, the 'thick' qualitative descriptions and stories shared by these educators cum learning technologists provide a glimpse into the realities of English teaching and learning at a time of 'disruptions' linked to Industry 4.0 and Education 4.0.

Keywords: Education 4.0, Industry 4.0, learning skills, learning technologies, Malaysia, tertiary education Cite as: Adnan, A. H. M., Karim, R. A., Tahir, M. H. M., Kamal, N. N. M., Yusof, A. M. (2019). Education 4.0 Technologies, Industry 4.0 Skills and the Teaching of English in Malaysian Tertiary Education. Arab World English Journal, 10 (4), 330-343.

DOI: https://dx.doi.org/10.24093/awej/vol10no4.24 